\title{
MASSACHUSETTS AND THE MINIMUM WAGE
}

\author{
By H. LaRue Brown, \\ Chairman, Massachusetts Minimum Wage Commission, Boston.
}

\section{The Beginnings}

In 1911, representatives of a number of groups of Massachusetts people who had been studying social and industrial conditions and were particularly interested in the situation of our 350,000 working women, formed themselves into an organization for the purpose of presenting to the legislature some sort of definite proposal looking toward remedial legislation to meet certain conditions which seemed to be getting worse instead of better as time went on.

They knew that for more than fifteen years there had been a movement in the Antipodes which had started in Melbourne and had spread to all the parts of the present Australian Commonwealth and to New Zealand which dealt with the question of depressed wages and unenlightened employers by compelling the paying of a certain minimum wage fixed under public authority. They knew that, upon the whole, the results of that system of dealing with the question had been satisfactory and that in the light of those results and after careful consideration of their own situation, similar legislation had been accepted and put into operation by the English parliament.

Knowing these facts and with some knowledge of our own conditions they felt that it was probable that similar legislation was needed in Massachusetts as in other states of the United States but they also realized that the one irresistible argument in support of proposed legislation is the presentation of facts so ascertained as to be accepted by the public, demonstrating the need of such legislation. Accordingly under advice of counsel they presented to our General Court in 1911 a petition asking for such an investigation as would develop the facts relating to this matter authoritatively. It was said frankly that the petitioners believed that such an investiga- 
tion would disclose conditions demanding remedy; and they said, "If it is a fact that there are in Massachusetts thousands of young women living in a state of semi-starvation, surrounded by terrible temptation, facing a prospect in which they are prematurely old, under-nourished, easy prey to disease and nervous collapse, unfit for motherhood, losing in self-respect and looking forward only to an old age of dependence, it is not only matter for wonder that so many are so patient, so uncomplaining and so good, but it is our imperative duty to set our house in order."

\section{The Investigating Commission}

The prima facie case made by the petitioners with such evidence as was already at their disposal so impressed the legislature that, without attracting much public attention, a resolve was passed creating an investigating commission upon whose report the legislation of 1912 was framed. That commission was handicapped by limitations of time and of funds but it did remarkable work. It could hardly be said to have been prejudiced in favor of the principle of a legal minimum wage because at least three of its five members knew practically nothing about the principle at the time of their appointment. But it set out to find out facts. And the facts were mighty convincing.

I think it is a just tribute to say that the present status of the minimum wage in Massachusetts and, what is more important the great awakening of our public conscience as to the question of our working girls is chiefly due to the enthusiasm, the hard work and the inspiring influence of one of those splendid women who devote themselves to making this old world a better place for us all, Mrs. Elizabeth Glendower Evans of Boston.

The commission did two things:

1. It made a most enlightening report covering about fifteen thousand working women in Massachusetts which is filled with facts as to wages and living conditions which cry out aloud for remedy.

2. It recommended the passage of legislation providing for the determination, for each of those trades in which the condition of the women employed seemed to demand it, of a legal minimum wage through the agency of wage boards made up of representatives of the workers and employers engaged in the particular trade together with representatives of the public which were to investigate the situa- 
tion in detail and to arrive at a conclusion under the supervision of a permanent commission created by the commonwealth.

There was no difference of opinion between the members of the commission as to the need of some legislation, although the particular conditions of the sweated trades are not so acute with us in Massachusetts as they are in many other communities and although it was the conditions in these trades that usually have been the exciting cause of the beginning of such legislation. There was a difference of opinion as to whether the law should be so framed as to compel by direct punitive action the payment of the wages so agreed upon. Four of five members of the commission united in recommending a coercive law. In so doing, they safeguarded the interests of the employers by requiring a two-thirds vote of the wages board to give their finding, if approved by the permanent minimum wage commission, that effect

\section{The Legislation of 1912}

When this report came before our General Court, the fight opened in earnest. The proposal was denounced as socialistic, as revolutionary, as subversive of the conservative traditions of the commonwealth and as fatal to the continuance of our industries; all of which, it was predicted, would immediately pack up their belongings and depart from an ungrateful community. Ours is a conservative commonwealth, and yet we are proud of the fact that it has on the whole been an intelligent conservatism with a very strong tincture of what is sometimes called idealism but ought rather to be called enlightened common sense. In dealing with social and industrial questions this has been especially true and the Bay State has stood in the very forefront of advance in dealing with these matters.

Last spring, there were abroad those things which made even our "Tories" stop and think, while the electric lights of Lawrence were distorting the shadows of bayonets into question marks which those who intended running in November could read without difficulty.

Out of all the contending forces and over the most decided sort of opposition there came the minimum wage act of 1912 . It was a compromise but a compromise which the believers in the measure were willing to accept as marking a great advance. The law establishes a permanent Minimum Wage Commission with authority to set in motion the machinery of investigation, and to give wide public- 
ity to the facts so ascertained. To the point of approval and promulgation of a minimum rate determined for the industry in question by a wages board composed of representatives of the workers, of the employers and of the public there is no change from the bill recommended by a majority of the Investigating Commission. The commission can not compel the payment of the rate which it recommends. Herein lay the practical compromise that was necessary to obtain the passage of any legislation. But the commission can give the widest publicity to the facts which it finds to exist and also it can tell the people of the commonwealth what employers follow and what employers do not follow its recommendations.

\section{The Probable Results of the Law}

The law does not go fully into effect until July 1 of this year. Awaiting that time our people who are acquainted with the situation are divided into three classes. There are those who feel that the law does not go far enough to be at all effective and that it should at once be given "teeth" by being made compulsory. There are those who believe that any statutory interference with wages is a wicked and impious thing and therefore that the present law or any law involving this principle goes too far.

To the stalwart objectors should logically be added, curiously enough, those thoroughgoing socialists who are the particular aversion of the individualists who make up its bulk. While the latter object to any such legislation as "socialistic" and therefore wholly bad, the more extreme socialists object to it with equal vehemence on the ground that it is a recognition of the wage system and therefore is utterly to be condemned as tending to perpetuate that manner of doing society's business.

Finally there are those who perhaps have thought most about the problem, whose effort really brought about there being any law at all of this character on our books. For them I may claim to be in some degree a spokesman and I think there is no doubt that they feel that while the law is weak in some respects and will in operation show defects that will require perfecting and strengthening amendment, it is, as it stands, an instrument of publicity of the greatest importance. That it is by no means certain that it will not in many cases produce the final results desired as rapidly and as effectually as a compulsory 
law could do and with much less difficulty and that in any event it should be given a fair trial both that we may keep faith with the legislature which passed the act with our assent and in order that we may go about remedying its defects intelligently, guided by the light of actual experience.

It may be said with much force that the movement has already more than justified itself in its effects upon the public conscience; in that it has sharply directed attention to sore spots in our social and industrial organization to which too little intelligent thought had been given in the past; and in that already it has caused many of our employers to consider their own houses and to begin to plan to set them in order. Nor is this a phenomenon limited to Boston. While the example of a large and successful Boston department store has been a beacon light to those wishing to do the right but not clearly seeing the way, it is a source of great satisfaction that a great national organization of merchants having had their attention directed to the problem and to the unbusinesslike and as well as the unethical way in which it had been slighted have set about considering how they best can meet it without waiting for the spur of legislation to compel their action.

That on the whole it was recognized that there was need of some legislation of this character and that it was thought that the law enacted offered some prospect of progress toward the solution of the question or at least toward ascertaining the facts necessary for its solution would seem to be a fair inference from the fact that despite earnest opposition at various public meetings at which the matter was discussed and before the legislative committees which passed upon it, but one vote against it could be mustered in the two houses of the legislature. It was of course not a party measure but was supported by Democrats, Republicans and progressives of all shades of opinion. It was not a "labor" measure but received the consistent support of organized labor although organized labor is that class of labor least in need of assistance of this character.

It is not believed by the most ardent of those who supported the measure that it will prove a panacea. It probably should be regarded only as an important part of a general program of social advance. It may not, of itself, completely do even the one thing against which it is directed. But we have been a long time doing anything at all toward relieving the evil. And we believe that this will do much. 


\section{The Difficulties}

That there are serious difficulties to be overcome in working out legislation of this character is undoubted. In some respects they may be less serious than in the case of more radical legislation but they are serious enough. Some of them are merely administrative. Others go to the fundamentals of the great problem of employment and efficiency in business.

Most of the difficulties however either are more apparent than real or else merely indicate the necessity for careful thought and considered action. For example, opponents of this legislation have much to say about the "inefficients" who are to be crowded out of employment, the girls who are not "worth" wages sufficient to keep them in health. It is argued most seriously that it will necessarily involve a most serious hardship to the community if our employers are told that they can not longer half-starve all of their employees because the result will be wholly to starve a few.

Where the question is not merely one of experience, which is dealt with later, it is first to be observed that there is nothing which makes for inefficiency like hunger, worry and discontent. As a rule you can be sure that the underpaid girl is hungry, that she is a victim of nearly continual worry, that she is overworked because she is trying to do her own cooking and washing as well as her work in the shop and that she is not getting the food and the care to keep her in condjtion to do good work even if her mental attitude could be such as to inspire it. No man can say how many of the girls now said to be inefficient and "not worth" the miserable wages paid would not be worth a higher wage if they were paid it. Service like many other things is apt to be worth about what it costs. If this sort of service were paid for under conditions which made for efficiency, it is very likely that the service would become efficient in proportion.

Where the inefficiency results from inexperience or disability, whether from age or other causes, it is quite easy to take care of such special classes and also to safeguard the exemption from abuse. The foreign statutes indicate clearly the manner in which this is to be done. It may however be assumed that there would be a certain irreducible minimum which would not do. If this proved to be so because the case was one of trying to fit square pegs in round holes, the remedy obviously is to put those pegs where the holes are square and procure round pegs for the holes left vacant. Finally, if there 
are some who are inefficient just out of sheer "cussedness" it were better that they should be out of industry altogether and that we get them out where we can see them, tell how many there are and make up our minds directly what to do with them. That is the businesslike way to meet that situation.

\section{The Business of It}

That suggests the argument which the advocates of this sort of legislation should make in season and out. Namely that we need to have a change even if we have to compel it in our present method of dealing with the underpaid working girls for cold business reasons if for no other. It is axiomatic that you pay more for that for which you pay indirectly. There is the cost of transmission, if there is nothing else. It is equally axiomatic that you can not get something for nothing.

There have been several efforts to determine what is the least amount of money that must be spent to keep an adult human being alive and in such physical condition as to enable efficient work. The sum has been fixed as high as $\$ 10.50$ per week for a girl living in one of our large eastern cities. Even if it is as low as $\$ 8$ it is certain that there are many thousands of women who give all that they can in the way of time and labor and who receive less than that amount.

Now as a proposition of mathematics, if a girl must spend $\$ 8.00$ to keep alive and reasonably efficient and she only gets $\$ 6.00$ the difference between $\$ 8$ and $\$ 6$ is being accounted for in some other way. It may be accounted for in the millions spent in public and private charity. It may be accounted for in an attempt to stretch the meagre earnings of some other person, thereby compelling the industry that employs that person not only to support its own labor but to bear part of the cost of providing labor for some other industry. And it must be remembered that nearly one-third of the thousands of women who work for wages are entirely dependent upon those wages for legitimate support and in many cases are bearing all or part of some other person's burdens.

It may be accounted for by compelling a resort to various means of supplementing a girl's income of which the most obvious though in the final analysis not the most serious in its consequences is the terrible means of prostitution.

In some cases the difference is taken care of by the fact that the girl is able to live at something less than cost in the various endowed 
homes, and in that case we are making up the difference in that it is our money that created those endowments.

Whenever the difference is made up in any of those ways, the people pay the difference and since they pay indirectly they necessarily pay more. From that point of view, then, a method of conducting society's business which involves the payment of wages less than the cost of existence is an uneconomical, and inefficient and thoroughly unbusinesslike system of social and industrial organization.

Where the difference is not so made up, we pay in yet a more wasteful and terrible way for then we pay in the most valuable asset society can have, in the health and strength, in the shattered nerves and weakened constitutions, in the physical ruin of those girls who should be fit to be mothers of efficient American citizens. Terrible in itself, such a situation is appalling in its consequences. For it means that we are drawing on the fundamental assets of the race and upon our reserve for the future.

I have mentioned the relation between low wages and vice. I think it exists. But I think that it is very easy to exaggerate. I live in a community where most of our girls are working girls. Many of them go from homes of poverty to toil long hours for low wages. Life for them has but little joy. It offers little opportunity for being a woman instead of a mere machine or adjunct to a machine. They are compelled daily and hourly to face temptation the more seductive in the contrast it offers to a starved and pleasureless existence. They meet it as a matter of course and without credit, bravely and honorably and it is an inspiring and ennobling thing that so very few give up what must to so many seem an unequal fight. It is not in prostitution that chiefly we pay the physical cost of insufficient wages. It is with the bodies of good girls, straight, honest and sweet that we pay.

\section{The Justification of Legislative Interference}

It requires no legislative enactment to persuade a man to give his horses enough to maintain them in such condition of health as to make it possible for them to do effective work. The reason is perfectly obvious. If one does not feed a horse sufficient to keep him alive, he will die. If he dies, one must lay out good money to get a new horse. Therefore, it is obvious that it pays to keep one's horse alive. But if a girl dies or drops from the ranks broken down, it costs nothing to replace her beyond an inexpensive advertisement for help. 
The result is twofold. In the first place the situation is not brought forcibly to the attention of the kind of employer who would not permit it to go on if he realized what it was and what it meant. In the second place it encourages the "scab" employer, who cares for nothing except profits, to continue to run his business on the system by which he does not treat his girls as well as his horses. By no means other than investigation backed and supervised by the authority of the state, can the facts be brought out in such a manner that their existence and importance can not be overlooked, and by no way other than by giving these facts the widest publicity and subjecting the conditions to supervision and perhaps even to the coercive control of the State, can this scab employer be compelled to deal fairly by society upon which he depends for existence; or can the fair employer be properly protected from the unfair competition of the unscrupulous.

We believe that nine business men out of ten would gladly do what is right realizing that their's is a wider responsibility than merely carrying on "their own business." We believe that they will do what is right when they are shown, after investigation in which they have a chance to present the thing as it looks from the angle from which they are necessarily best able to view it, what the right appears to be. We believe that no business worth keeping can exist for whose products the public is notwilling to pay a price sufficient to permit payment by those engaged in it of wages sufficient to keep the workers who devote themselves to it at a fair state of health and efficiency. We believe that this measure, while not a complete remedy for all the evils with which it deals, is a sane attempt to do something in an intelligent, businesslike manner to relieve a most serious situation. It seeks first to diagnose the difficulty and then go about curing it in the light of trustworthy information as to the problem and it is essentially conservative.

Conservatism does not consist of trying to keep still. You can no more do that than can an oarsman in a flowing river remain opposite a certain mark on the bank if he sits with folded arms. We may do nothing but events march. This minimum wage movement is a part of the great scheme of social advance which having regard to the practical necessities of our situation is moving on to the end that this shall be a good world not only for some of us but for all of us to live in. It is as true today as when St. Augustine said it, "You give your bread to feed the hungry. But it were better that none hungered and you had none to give." 